Journal of Clinical Investigation
Vol. 42, No. 8, 1963

\title{
THE MECHANISM OF SODIUM DIURESIS AFTER SALINE INFUSION IN THE DOG *
}

\author{
By NORMAN G. LEVINSKY † AND RICHARD C. LALONE wITH THE \\ TECH NICAL ASSISTANCE OF IRMA S. MOSS \\ (From the Fifth and Sixth [Boston University] Medical Services, Boston City Hospital, and the \\ Department of Medicine, Boston University School of Medicine, Boston University \\ Medical Center, Boston, Mass.)
}

(Submitted for publication March 5, 1963 ; accepted April 11, 1963)

When dogs are fed or infused with sodium chloride, sodium excretion and glomerular filtration rate (GFR) both increase. Since filtered sodium usually increases more than sodium excretion $(1,2)$, it is commonly assumed that the sodium diuresis can be explained by the increase in filtered load (3). It has occasionally been suggested, however, that augmented sodium excretion is due to decreased tubular reabsorption of sodium rather than to increased filtration. For example, de Wardener, Mills, Clapham, and Hayter (4) recently reached this conclusion from experiments in which saline was infused into mineralocorticoid-treated dogs. In about one-half of their studies, sodium excretion increased in spite of apparent decreases in GFR.

The error of measurement of GFR is probably about $5 \%$ (5). Since sodium excretion even at the height of a saline diuresis is usually a small fraction of filtered sodium, it is difficult to rule out the possibility that small errors in measurement are sufficient to account for occasional instances of apparent dissociation between filtered and excreted sodium. To circumvent this difficulty in the present experiments, an aortic clamp has been used to reduce GFR reproducibly below control levels after saline loading in dogs treated with mineralocorticoids. Since under these conditions sodium excretion is nevertheless increased above control rates, part of the sodium diuresis that follows saline administration in the dog must be due to a factor other than increased filtered load or decreased mineralocorticoid activity.

* Supported by U. S. Public Health Service research grants HE-06795 (National Heart Institute) and A-5589 (National Institute of Arthritis and Metabolic Diseases), Bethesda, Md.

$\dagger$ Address correspondence to: 15 Stoughton St., Boston 18, Mass.

\section{METHODS}

Female mongrel dogs weighing 10 to $20 \mathrm{~kg}$ were anesthetized with iv sodium pentobarbital, $30 \mathrm{mg}$ per $\mathrm{kg}$; supplemental doses were given as necessary to maintain light anesthesia. The aorta was approached retroperitoneally by a left subcostal incision; a modified Blalock clamp was placed around the aorta above the renal arteries and fixed to supporting tissues. To confirm that the clamp was situated above both renal arteries, it was closed for a few moments to demonstrate that urine flow stopped completely. Urine was collected from a retention catheter in the bladder.

Eighteen hours before an experiment, food and water were withdrawn. At this time, each dog was given $10 \mathrm{mg}$ of desoxycorticosterone acetate (DOCA) in oil and $5 \mathrm{U}$ of vasopressin tannate in oil intramuscularly. One-half hour before an experiment, each dog received $5 \mathrm{mg}$ of DOCA in oil. (In a few cases, the medications 18 hours before the experiment were omitted. These dogs received $10 \mathrm{mg}$ of DOCA in oil and $5 \mathrm{U}$ of vasopressin tannate in oil $\frac{1}{2}$ hour before the experiments.) Throughout each experiment all dogs received an infusion containing either $9 \alpha$-fluorocortisol or 2 -methyl-9 $\alpha$-fluorocortisol.1 In three experiments, $d$-aldosterone was also given intravenously. The approximate amounts of mineralocorticoid infused were as follows : 2-methyl-9 $\alpha$-fluorocortisol or $9 \alpha$-fluorocortisol, a priming dose of 0.5 to $2.0 \mathrm{mg}$ and a sustaining rate of 0.5 to $4 \mu \mathrm{g}$ per minute; and $d$-aldosterone, a priming dose of $0.5 \mathrm{mg}$ and a sustaining rate of $1 \mu \mathrm{g}$ per minute.

The sustaining infusion also contained inulin and $p$ aminohippuric acid ( $\mathrm{PAH}$ ) enough for the measurement of renal clearances, and was given at about $0.4 \mathrm{ml}$ per minute. Sodium loading was accomplished by infusing either $0.82 \%$ saline or a modified Ringer's solution (140 $\mathrm{mEq}$ per $\mathrm{L}$ sodium, $5 \mathrm{mEq}$ per $\mathrm{L}$ potassium, $119 \mathrm{mEq}$ per $\mathrm{L}$ chloride, and $26 \mathrm{mEq}$ per $\mathrm{L}$ bicarbonate). These infusions were given at about $30 \mathrm{ml}$ per minute initially, until the dogs had received a total of $400 \mathrm{ml}$. Thereafter, the rate of infusion was about 10 to $12 \mathrm{ml}$ per minute, except that the sodium infusion was occasionally reduced to 2 to $5 \mathrm{ml}$ per minute later in an experiment if urine flow was very low.

1 Both supplied through the courtesy of Dr. Harold L. Upjohn of the Upjohn Company, Kalamazoo, Mich. 
The 53 experiments reported are of eight types. At least three clearance measurements are included in each group of periods. Control periods were not obtained until sodium excretion had been stable for at least 1 hour. 1) "Diuresis first." Control periods were obtained. Saline was infused and period collections were made during the subsequent diuresis when urine flow had become relatively stable. The aortic clamp was then closed until sodium excretion fell to approximately 25 to $200 \mu \mathrm{Eq}$ per minute above the control rate, and "clamp" period collections were made. 2) "Immediate clamping." Control period collections were made. Infusion of saline was begun, and the clamp was immediately adjusted in an attempt to keep sodium excretion no more than $200 \mu \mathrm{Eq}$ per minute above the control rate. When a stable setting was achieved, "clamp" period collections were made. In most experiments, the clamp was then opened, and additional measurements were made during the subsequent diuresis. 3) "Double loading." Saline was infused initially, and control period collections were made during the ensuing diuresis. An additional infusion of saline was then given and collections made during the enhanced diuresis. Finally, the clamp was set to reduce sodium excretion to approximately 100 to $200 \mu \mathrm{Eq}$ per minute above control, and "clamp" period collections were made. 4) Control. After control period collections, the clamp was set to reduce urine flow 25 to $50 \%$ below the control rate. "Clamp" period collections were then made. In a few experiments, additional clearance measurements were made after the clamp had been released. 5) "Saline infusions." Control period collections were made. After several hundred $\mathrm{ml}$ of saline had heen given rapidly, the infusion rate was slowed; clearance period collections were made when urine flow was stable. Additional amounts of saline were subsequently administered three or four times in a similar fashion, and a set of clearance period collections was made after each additional infusion. 6) Albumin infusions. These experiments were done according to the "diuresis first" protocol, except that bovine albumin, $7 \mathrm{~g}$ per $100 \mathrm{ml}$, was added to the saline infusion. The albumin solution was infused at the usual rates until a fixed volume ( 500 to $2,000 \mathrm{ml}$ ) had been given, and then discontinued. 7) Adrenalectomized dogs. Experiments of the "diuresis first" and "immediate clamping" types were done on dogs adrenalectomized at least 1 week before. These dogs had been maintained on 25 $\mathrm{mg}$ of cortisone and a high-salt intake before use. 8) Angiotensin. Experiments were performed according to the "diuresis first" or "immediate clamping" protocols. An infusion of angiotensin 2 in 3\% dextrose was begun at least 1 hour before collection of the control periods and was continued throughout the experiment. The rate of the infusion was set in each experiment to elevate the blood pressure 10 to $30 \mathrm{~mm} \mathrm{Hg}$, measured by means of a catheter in the carotid artery connected to a damped mercury manometer. The amount of angiotensin required

${ }^{2}$ Hypertensin-Ciba, supplied by the Ciba Pharmaceutical Company, Summit, N. J., through the courtesy of Dr. A. A. Renzi. varied from 1 to $5 \mu \mathrm{g}$ per minute, delivered in a volume of 0.5 to $1 \mathrm{ml}$ per minute. The solution was administered either intravenously or into the aorta just above the renal arteries via a polyethylene catheter inserted through a femoral artery.

Filtered sodium is calculated as equal to $\mathrm{k} \times \mathrm{P}_{\mathrm{Na}} \times \mathrm{C}_{\mathrm{IN}}$. The Donnan factor $k$, was assumed to change proportionately with plasma protein concentration; at a plasma protein concentration of $6 \mathrm{~g}$ per $100 \mathrm{ml}$, the $\mathrm{k}$ for sodium was taken as 0.95 , for chloride as $1.023(6,7)$.

The analytical methods used were as follows: inulin, the diphenylamine method of Walser, Davidson, and Orloff (8); PAH, the method of Bratton and Marshall (9), as modified for use with the Auto-Analyzer ; ${ }^{3}$ sodium, internal standard flame photometry; chloride, the amperometric method of Cotlove (10); and plasma protein, a biuret method (11)

\section{RESULTS}

Diuresis first. The detailed protocol of one experiment is given in Table I; eight experiments of this type are summarized in Table IV A. In the control periods, sodium excretion was very low; filtered sodium averaged about $5 \mathrm{mEq}$ per minute. Saline was then infused, and about $1 \frac{1}{2}$ hours later sodium excretion had become reasonably stable at about $490 \mu \mathrm{Eq}$ per minute. This increase of some $460 \mu \mathrm{Eq}$ per minute in the rate of sodium excretion represented only about $60 \%$ of the simultaneous increase in filtered sodium. Sodium excretion was then reduced by means of the aortic clamp to about $250 \mu \mathrm{Eq}$ per minute. Subsequent analysis showed that filtered sodium was about $2.9 \mathrm{mEq}$ per minute during these periods, a value well below the control rate. By further closure of the clamp, sodium excretion was then reduced to just above $100 \mu \mathrm{Eq}$ per minute. It was later found that filtered sodium had decreased still further, to about one-half the control value. Thus, in both sets of "clamp" periods, although sodium excretion was well above control, filtered sodium was markedly below control. The results were qualitatively similar with respect to excreted and filtered chloride.

The volume of saline or Ringer's solution infused by the end of the "clamp" periods varied from 1,600 to $2,700 \mathrm{ml}$ in the 8 "diuresis first" experiments. Increased sodium excretion in the face of decreased filtered sodium was found in 7 of the 8 experiments (Table IV A). In experiment 7 , filtered sodium in the "clamp periods"

3 Technicon Instruments Corporation, Chauncey, N. Y. 
TABLE I

Representative "diuresis first" experiment*

\begin{tabular}{|c|c|c|c|c|c|c|c|c|c|c|}
\hline Time & $\mathrm{V}$ & Cin & СРaн & P Prot & $\mathrm{P}_{\mathrm{Na}}$ & $\mathbf{F}_{\mathbf{N a}}$ & $\mathrm{UNaV}_{\mathrm{Na}}$ & $\mathrm{Pcl}$ & $\mathrm{FCl}_{\mathrm{Cl}}$ & UcıV \\
\hline $\begin{array}{l}\min \\
-30\end{array}$ & \multicolumn{9}{|c|}{5 mg DOCA intramuscularly } & $\mu E q / \min$ \\
\hline 0 & \multicolumn{10}{|c|}{$\begin{array}{l}\text { Priming dose given: } 300 \mathrm{mg} \text { inulin, } 400 \mathrm{mg} \text { PAH, } 0.5 \mathrm{mg} \text { 2-methyl-9 } \alpha \text {-fluorocortisol, } 0.5 \mathrm{mg} d \text {-aldo- } \\
\text { sterone }\end{array}$} \\
\hline & \multicolumn{10}{|c|}{  } \\
\hline $\begin{array}{l}173-189 \\
189-197 \\
197-205\end{array}$ & $\begin{array}{l}0.438 \\
0.438 \\
0.375\end{array}$ & $\begin{array}{l}35 \\
34 \\
34\end{array}$ & $\begin{array}{l}86 \\
78 \\
97\end{array}$ & $\begin{array}{l}5.5 \\
5.4 \dagger \\
5.3\end{array}$ & $\begin{array}{l}154 \\
154 \dagger \\
154\end{array}$ & $\begin{array}{l}5.14 \\
5.00 \\
5.00\end{array}$ & $\begin{array}{l}36 \\
25 \\
23\end{array}$ & $\begin{array}{l}122 \\
121 \dagger \\
120\end{array}$ & $\begin{array}{l}4.36 \\
4.20 \\
4.17\end{array}$ & $\begin{array}{l}42 \\
32 \\
26\end{array}$ \\
\hline 220 & \multicolumn{10}{|c|}{ Infusion II started: $0.82 \% \mathrm{NaCl}$ at $30 \mathrm{ml} / \mathrm{min}$ for $500 \mathrm{ml}$, then slowed to $12 \mathrm{ml} / \mathrm{min}$} \\
\hline $\begin{array}{l}299-304 \\
304-309 \\
309-314 \\
314-319\end{array}$ & $\begin{array}{l}5.20 \\
5.20 \\
5.00 \\
5.00\end{array}$ & $\begin{array}{l}40 \\
38 \\
38 \\
38\end{array}$ & $\begin{array}{l}125 \\
121 \\
115 \\
124\end{array}$ & $\begin{array}{l}2.5 \\
2.6 \dagger \\
2.5 \dagger \\
2.6\end{array}$ & $\begin{array}{l}153 \\
154 \dagger \\
154 \dagger \\
154\end{array}$ & $\begin{array}{l}5.99 \\
5.73 \\
5.73 \\
5.73\end{array}$ & $\begin{array}{l}497 \\
499 \\
476 \\
474\end{array}$ & $\begin{array}{l}132 \\
133 \dagger \\
133 \dagger \\
133\end{array}$ & $\begin{array}{l}5.33 \\
5.10 \\
5.10 \\
5.10\end{array}$ & $\begin{array}{l}445 \\
448 \\
424 \\
424\end{array}$ \\
\hline 320 & \multicolumn{8}{|c|}{ Closure of aortic clamp begun } & \multicolumn{2}{|l|}{$i$} \\
\hline 340 & \multicolumn{10}{|c|}{ Desired clamp setting obtained } \\
\hline $\begin{array}{l}346-352 \\
352-358 \\
358-364 \\
364-370\end{array}$ & $\begin{array}{l}2.33 \\
2.67 \\
2.87 \\
3.00\end{array}$ & $\begin{array}{l}19 \\
20 \\
20 \\
19\end{array}$ & $\begin{array}{l}60 \\
57 \\
55 \\
55\end{array}$ & $\begin{array}{l}2.3 \\
2.3 \dagger \\
2.2 \\
2.1\end{array}$ & $\begin{array}{l}153 \\
153 \dagger \\
153 \\
153\end{array}$ & $\begin{array}{l}2.85 \\
3.00 \\
3.01 \\
2.86\end{array}$ & $\begin{array}{l}212 \\
247 \\
267 \\
286\end{array}$ & $\begin{array}{l}136 \\
136 \dagger \\
136 \\
137\end{array}$ & $\begin{array}{l}2.61 \\
2.75 \\
2.75 \\
2.63\end{array}$ & $\begin{array}{l}186 \\
221 \\
244 \\
265\end{array}$ \\
\hline 372 & \multicolumn{10}{|c|}{ Infusion II slowed to $6 \mathrm{ml} / \mathrm{min}$ and further closure of aortic clamp begun } \\
\hline 400 & \multicolumn{10}{|c|}{ Desired clamp setting obtained } \\
\hline $\begin{array}{l}417-423 \\
423-429 \\
429-435\end{array}$ & $\begin{array}{l}1.33 \\
1.42 \\
1.42\end{array}$ & $\begin{array}{l}17 \\
16 \\
17\end{array}$ & $\begin{array}{l}41 \\
40 \\
37\end{array}$ & $\begin{array}{l}2.3 \\
2.3 \dagger \\
2.3\end{array}$ & $\begin{array}{l}151 \\
151 \dagger \\
150\end{array}$ & $\begin{array}{l}2.51 \\
2.37 \\
2.50\end{array}$ & $\begin{array}{l}102 \\
109 \\
107\end{array}$ & $\begin{array}{l}137 \\
137 \dagger \\
137\end{array}$ & $\begin{array}{l}2.35 \\
2.21 \\
2.35\end{array}$ & $\begin{array}{l}80 \\
89 \\
88\end{array}$ \\
\hline
\end{tabular}

* Abbreviations are as follows: $\mathrm{V}=$ urine flow, $\mathrm{CIN}_{\mathrm{IN}}=$ inulin clearance, $\mathrm{CPAH}=p$-aminohippurate clearance, $\mathrm{P}_{\mathrm{Prot}}=$ plasma protein, $\mathrm{P}_{\mathrm{Na}}=$ plasma sodium, $\mathrm{F}_{\mathrm{Na}}=$ filtered sodium, $\mathrm{U}_{\mathrm{Na}} \mathrm{V}=$ sodium excretion, $\mathrm{P}_{\mathrm{Cl}}=$ plasma chloride $\mathrm{F}_{\mathrm{Cl}}=$ filtered chloride, $\mathrm{U}_{\mathrm{Cl}} \mathrm{V}=$ chloride excretion, and $\mathrm{DOCA}=$ desoxycorticosterone acetate.

† Interpolated value.

was $80 \mu \mathrm{Eq}$ per minute above control, while sodium excretion was $132 \mu \mathrm{Eq}$ per minute higher.

In all experiments, both filtered sodium and sodium excretion were above control in the postsaline periods collected without clamping ("diuresis" periods, Table IV A). The increase in excretion was a very variable proportion of the increase in filtered sodium, ranging between 7 and $112 \%$. In all cases except experiment 8, however, the increase in filtered sodium during the "diuresis" periods is sufficient to account for the increase in excretion.

Immediate clamping. In these experiments, the aortic clamp was set at the start of the saline infusion. It was thus possible to collect the "clamp" periods after the control periods without an intervening diuresis in order to explore the possibility that the prior diuresis might itself in some way condition the increased sodium excretion found in the "clamp" periods of the "diuresis first" experiments. One experiment is presented in detail in Table II ; nine experiments are summarized in Table IV B. In this experiment, closure of the aortic clamp was begun within 2 minutes after the modified Ringer's solution had been started. At no time during the next part of the experiment did urine flow exceed 1 to $2 \mathrm{ml}$ per minute. After a number of attempts, an appropriate clamp setting was obtained at which sodium excretion was about $80 \mu \mathrm{Eq}$ per minute above the control rate. Later analysis indicated that filtered sodium was about $800 \mu \mathrm{Eq}$ per minute less in the "clamp" than in the control periods. After the "clamp" periods had been collected, the clamp was released. Urine flow increased promptly, and a brisk sodium diuresis developed. The filtration rate increased 15 $\mathrm{ml}$ per minute, a value $8 \mathrm{ml}$ per minute above the control GFR. 
The volume of saline or Ringer's solution infused up to the end of the "clamp" periods varied from about 1,400 to $2,700 \mathrm{ml}$ in the 9 "immediate clamping" experiments. In 7 of the experiments, the results were qualitatively similar; an increase in sodium excretion was present during the "clamp" periods in spite of a decrease in filtered sodium. In experiments 9 and 10, small increases in filtered sodium, approximately equal to the respective increases in sodium excretion, were present in the "clamp" periods.

In 6 experiments, clearance periods were collected after the aortic clamp had been released. In each case, sodium excretion had increased during these "diuresis" periods. In experiments 9, 14 , and 17 , the increase in sodium excretion between the control and the "diuresis" periods was associated with a more than equivalent increase in filtered sodium. In experiments 11 and 16, filtered sodium was decreased in the "diuresis" periods, as compared to the controls; yet sodium excretion was increased about 300 and $200 \mu \mathrm{Eq}$ per minute, respectively. Each of these dogs had received about $2,500 \mathrm{ml}$ of saline before the collection of the "diuresis" periods. In experiment 12 , sodium excretion was over $1,000 \mu \mathrm{Eq}$ per minute higher than the control rate during the "diuresis" periods, although filtered sodium in the "diuresis" periods was slightly below control. This dog had received only $1,800 \mathrm{ml}$ of saline before the "diuresis" periods.

Double loading. In the experiments described above, in which the control rate of sodium excretion was very low, it was found that part of the increase in sodium excretion after saline infusion was not related to increased filtered sodium. To determine whether this is also the case when the rate of excretion during saline diuresis is further increased by additional saline loading, the five experiments summarized in Table IV $\mathrm{C}$ were performed. Data from one experiment are given in detail in Table III. Before the collection of the control periods, this dog had been infused with a volume of saline equivalent to that regularly given in experiments of the "diuresis first" and "immediate clamping" types. Sodium excretion in the

TABLE II

Representative "immediate clamping" experiment*

\begin{tabular}{|c|c|c|c|c|c|c|}
\hline Time & $\mathrm{v}$ & Cin & PProt & $\mathbf{P}_{\mathrm{Na}}$ & $\mathrm{F}_{\mathrm{Na}}$ & $\mathrm{UNaV}_{\mathrm{Na}}$ \\
\hline $\begin{array}{l}\min \\
-30\end{array}$ & $\mathbf{m l} / \mathrm{min}$ & $\begin{array}{l}m l / m i n \\
\text { intram }\end{array}$ & $\begin{array}{l}g / 100 \mathrm{ml} \\
\text { arly }\end{array}$ & $m E q / L$ & $m E q / \min$ & $\mu E q / \min$ \\
\hline 0 & \multirow{2}{*}{\multicolumn{6}{|c|}{$\begin{array}{l}\text { Priming dose given: } 300 \mathrm{mg} \text { inulin, } 400 \mathrm{mg} \text { PAH, } 0.5 \mathrm{mg} 2 \text {-methyl-9 } \alpha \text {-fluorocortisol } \\
\text { Infusion I started: } 5.9 \mathrm{mg} / \mathrm{min} \text { inulin, } 5 \mathrm{mg} / \mathrm{min} \mathrm{PAH}, 50 \mathrm{mU} / \mathrm{kg} / \mathrm{hr} \text { vasopressin, and } 0.84 \\
\mu \mathrm{g} / \mathrm{min} 2 \text {-methyl-9 } \alpha \text {-fluorocortisol in } 3 \% \text { dextrose solution at } 0.4 \mathrm{ml} / \mathrm{min}\end{array}$}} \\
\hline & & & & & & \\
\hline $\begin{array}{l}261-267 \\
267-273 \\
273-285\end{array}$ & $\begin{array}{l}1.25 \\
1.25 \\
1.17\end{array}$ & $\begin{array}{l}65 \\
68 \\
67\end{array}$ & $\begin{array}{l}\mathbf{5 . 4} \\
\mathbf{5 . 4} \dagger \\
\mathbf{5 . 4}\end{array}$ & $\begin{array}{l}148 \\
149 \dagger \\
149\end{array}$ & $\begin{array}{l}9.18 \\
9.64 \\
9.59\end{array}$ & $\begin{array}{l}78 \\
80 \\
81\end{array}$ \\
\hline 305 & \multicolumn{6}{|c|}{$\begin{array}{l}\text { Infusion II started: } 114 \mathrm{mM} / \mathrm{L} \mathrm{NaCl}, 26 \mathrm{mM} / \mathrm{L} \mathrm{NaHCO} \text {, and } 5 \mathrm{mM} / \mathrm{L} \mathrm{KCl} \text { in water at } \\
\qquad 30 \mathrm{ml} / \mathrm{min} \text { for } 400 \mathrm{ml} \text {, then slowed to } 12 \mathrm{ml} / \mathrm{min}\end{array}$} \\
\hline 307 & \multicolumn{6}{|c|}{ Closure of aortic clamp begun } \\
\hline 419 & \multicolumn{6}{|c|}{ Infusion II slowed to $2 \mathrm{ml} / \mathrm{min}$} \\
\hline 435 & \multicolumn{6}{|c|}{ Desired clamp setting obtained } \\
\hline $\begin{array}{l}456-462 \\
462-468 \\
468-480\end{array}$ & $\begin{array}{l}1.25 \\
1.13 \\
0.96\end{array}$ & $\begin{array}{l}58 \\
58 \\
60\end{array}$ & $\begin{array}{l}3.7 \\
3.6 \\
3.6\end{array}$ & $\begin{array}{l}149 \\
148 \\
149\end{array}$ & $\begin{array}{l}8.44 \\
8.38 \\
8.68\end{array}$ & $\begin{array}{l}174 \\
175 \\
144\end{array}$ \\
\hline 486 & \multicolumn{6}{|c|}{ Clamp released } \\
\hline 487 & \multicolumn{6}{|c|}{ Infusion II increased to $12 \mathrm{ml} / \mathrm{min}$} \\
\hline $\begin{array}{l}550-555 \\
555-560 \\
560-565\end{array}$ & $\begin{array}{l}7.80 \\
8.30 \\
9.20\end{array}$ & $\begin{array}{l}76 \\
75 \\
75\end{array}$ & $\begin{array}{l}3.4 \\
3.3 \\
3.4\end{array}$ & $\begin{array}{l}149 \\
150 \\
150\end{array}$ & $\begin{array}{l}11.0 \\
10.9 \\
11.0\end{array}$ & $\begin{array}{l}1,014 \\
1,062 \\
1,178\end{array}$ \\
\hline
\end{tabular}

* Abbreviations as in Table I.

$\dagger$ Interpolated value. 
TABLE III

Representative "double loading" experiment*

\begin{tabular}{|c|c|c|c|c|c|c|c|c|c|}
\hline Time & $\mathbf{V}$ & Cin & Prot & $P_{\mathrm{Na}}$ & $\mathbf{F}_{\mathrm{Na}}$ & $\mathrm{UNaV}_{\mathrm{Na}}$ & Pci & $\mathbf{F}_{\mathbf{c l}}$ & UalV \\
\hline $\begin{array}{l}\min \\
-30\end{array}$ & \multicolumn{8}{|c|}{$10 \mathrm{mg}$ DOCA and 5 pressor $\mathrm{U}$ vasopressin tannate in oil intramuscularly } & $\mu E q / \min$ \\
\hline 0 & \multicolumn{9}{|c|}{ Priming dose given: $300 \mathrm{mg}$ inulin, $400 \mathrm{mg}$ PAH, $0.5 \mathrm{mg}$ 2-methyl-9 $\alpha$-fluorocortisol } \\
\hline & \multicolumn{9}{|c|}{$\begin{array}{c}\text { Infusion I started: } 5.9 \mathrm{mg} / \mathrm{min} \text { inulin, } 5 \mathrm{mg} / \mathrm{min} \mathrm{PAH}, 50 \mathrm{mU} / \mathrm{kg} / \mathrm{hr} \text { vasopressin, and } 0.9 \mu \mathrm{g} / \mathrm{min} \\
\text { 2-methyl-9 } \alpha \text {-fluorocortisol in } 3 \% \text { dextrose solution at } 0.4 \mathrm{ml} / \mathrm{min}\end{array}$} \\
\hline 75 & \multicolumn{9}{|c|}{ Infusion II started: $0.82 \% \mathrm{NaCl}$ at $30 \mathrm{ml} / \mathrm{min}$ for $500 \mathrm{ml}$, then slowed to $12 \mathrm{ml} / \mathrm{min}$} \\
\hline $\begin{array}{l}161-166 \\
166-171 \\
171-176 \\
176-181\end{array}$ & $\begin{array}{l}\mathbf{5 . 6} \\
5.2 \\
5.2 \\
5.3\end{array}$ & $\begin{array}{l}65 \\
63 \\
65 \\
64\end{array}$ & $\begin{array}{l}4.7 \\
4.6 \dagger \\
4.5 \\
4.4\end{array}$ & $\begin{array}{l}152 \\
152 \dagger \\
152 \\
153\end{array}$ & $\begin{array}{l}9.54 \\
9.28 \\
9.49 \\
9.44\end{array}$ & $\begin{array}{l}784 \\
733 \\
728 \\
731\end{array}$ & $\begin{array}{l}117 \\
118 \dagger \\
119 \\
112\end{array}$ & $\begin{array}{l}7.76 \\
7.61 \\
7.84 \\
7.30\end{array}$ & $\begin{array}{l}739 \\
754 \\
785 \\
774\end{array}$ \\
\hline 182 & \multicolumn{9}{|c|}{ Infusion II increased to $30 \mathrm{ml} / \mathrm{min}$ for $500 \mathrm{ml}$, then slowed to $20 \mathrm{ml} / \mathrm{min}$} \\
\hline $\begin{array}{l}240-245 \\
245-250 \\
250-255\end{array}$ & $\begin{array}{l}13.2 \\
13.2 \\
13.1\end{array}$ & $\begin{array}{l}\mathbf{5 7} \\
56 \\
57\end{array}$ & $\begin{array}{l}3.9 \\
3.9 \dagger \\
3.9\end{array}$ & $\begin{array}{l}144 \\
144 \dagger \\
144\end{array}$ & $\begin{array}{l}7.97 \\
7.81 \\
7.97\end{array}$ & $\begin{array}{l}1,439 \\
1,386 \\
1,415\end{array}$ & $\begin{array}{l}117 \\
118 \dagger \\
118\end{array}$ & $\begin{array}{l}6.79 \\
6.72 \\
6.85\end{array}$ & $\begin{array}{l}1,531 \\
1,465 \\
1,480\end{array}$ \\
\hline 257 & \multicolumn{9}{|c|}{ Closure of aortic clamp begun } \\
\hline 403 & \multicolumn{9}{|c|}{ Desired clamp setting obtained } \\
\hline $\begin{array}{l}418-423 \\
423-428 \\
428-433 \\
433-438\end{array}$ & $\begin{array}{l}8.1 \\
7.6 \\
8.4 \\
8.8\end{array}$ & $\begin{array}{l}49 \\
47 \\
44 \\
45\end{array}$ & $\begin{array}{l}3.1 \\
3.1 \dagger \\
3.1 \\
3.1\end{array}$ & $\begin{array}{l}144 \\
144 \dagger \\
144 \\
144\end{array}$ & $\begin{array}{l}6.92 \\
6.54 \\
6.18 \\
6.35\end{array}$ & $\begin{array}{l}875 \\
813 \\
907 \\
942\end{array}$ & $\begin{array}{l}117 \\
116 \dagger \\
114\end{array}$ & $\begin{array}{l}\mathbf{5 . 8 3} \\
5.47 \\
\mathbf{5 . 0 7}\end{array}$ & $\begin{array}{r}988 \\
936 \\
907 \\
1,038\end{array}$ \\
\hline
\end{tabular}

* Abbreviations as in Table I.

† Interpolated value.

control periods, therefore, was over $700 \mu \mathrm{Eq}$ per minute. After these periods had been collected, an additional volume of $500 \mathrm{ml}$ of saline was infused rapidly, and the rate of the sustaining saline infusion was increased to $20 \mathrm{ml}$ per minute. When the second group of periods was collected, an hour later, sodium excretion had increased to about twice the initial rate. Analysis subsequently



Fig. 1. Sodium in three types of experiments. Points represent mean changes, "clamp" minus control periods. 


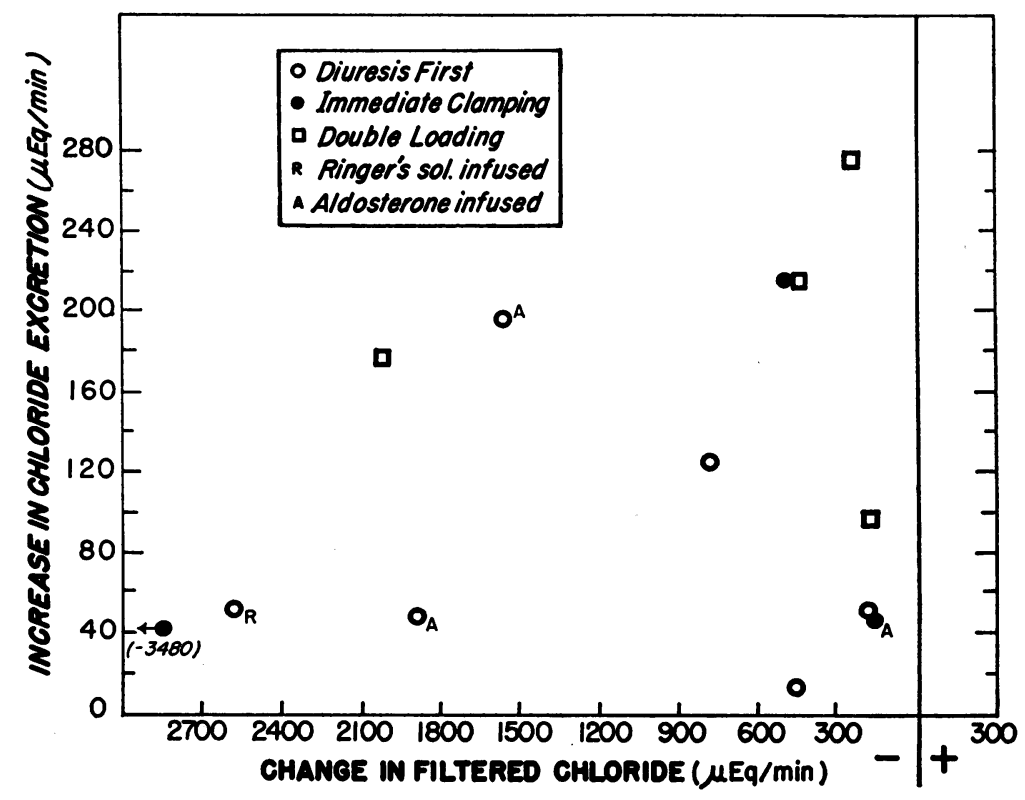

Fig. 2. Chloride in three types of experiments. Points represent mean changes, "clamp" minus control periods.

TABLE IV

Summary of experiments (types 1,2 , and 3$)^{*}$

\begin{tabular}{|c|c|c|c|c|c|c|c|c|c|c|c|c|c|c|}
\hline \multicolumn{5}{|c|}{ A. Diuresis first } & \multicolumn{5}{|c|}{ B. Immediate clamping } & \multicolumn{5}{|c|}{ C. Double loading } \\
\hline & Cin & $P_{\mathrm{Na}}$ & $\mathrm{F}_{\mathrm{Na}}$ & $\mathrm{UNaV}_{\mathrm{Na}}$ & & Cin & $\mathrm{P}_{\mathrm{Na}}$ & $\mathrm{F}_{\mathrm{Na}}$ & $\mathrm{U}_{\mathrm{Na}} \mathrm{V}$ & & Cin & $\mathrm{P}_{\mathrm{Na}}$ & $\mathbf{F}_{\mathrm{Na}}$ & $\mathrm{UNa}_{\mathrm{N}} \mathrm{V}$ \\
\hline & $\underset{m i n}{m l /}$ & $\underset{L}{m E q /}$ & $\min _{\min }$ & $\underset{\min }{\mu E q /}$ & & $\begin{array}{l}m i / \\
m i n\end{array}$ & $\underset{L}{m E q}$ & $\underset{\min }{\operatorname{meq} /}$ & $\underset{\min }{\mu E q /}$ & & $\min ^{m l /}$ & $\underset{L}{m E q}$ & $\underset{\min }{\operatorname{mEq} /}$ & $\underset{\min }{\mu E \boldsymbol{q} /}$ \\
\hline \multirow{4}{*}{$\begin{array}{l}\text { 1. ControlA } \\
\text { Diuresis } \\
\text { Clamp } \\
\text { Clamp }\end{array}$} & 34 & 154 & 5.05 & 28.0 & 9. Control & 55 & 153 & 7.92 & 84.3 & 18. Control & 64 & 152 & 9.44 & 744 \\
\hline & 38 & 154 & 5.80 & 487 & Clamp & 54 & 153 & 8.06 & 218 & Diuresis & 57 & 144 & 7.92 & 1413 \\
\hline & 20 & 153 & 2.93 & 253 & Diuresis & 59 & 156 & 8.91 & 839 & Clamp & 46 & 144 & 6.50 & 884 \\
\hline & 17 & 151 & 2.51 & 106 & 10. Control & 46 & 153 & 6.72 & 20.8 & 19. Control & 78 & 151 & 11.2 & 11.2 \\
\hline \multirow{4}{*}{$\begin{array}{l}\text { 2. Control } \\
\text { Diuresis } \\
\text { Clamp }\end{array}$} & 53 & 148 & 7.49 & 7.8 & Clamp & 46 & 150 & 6.73 & 45.8 & Clamp & 71 & 153 & 10.3 & 185 \\
\hline & 68 & 152 & 10.1 & 195 & & & & & & & & & & \\
\hline & 33 & 153 & 4.70 & 102 & 11. Control & 65 & 146 & 9.07 & 10.2 & 20. Control & 49 & 154 & 7.16 & 211 \\
\hline & & & & & Clamp & 31 & 144 & 4.38 & 79.9 & Diuresis & 50 & 153 & 7.40 & 713 \\
\hline \multirow{4}{*}{$\begin{array}{l}\text { 3. Control } \\
\text { DiuresisR } \\
\text { Clamp }\end{array}$} & 76 & 130 & 9.44 & 117 & Diuresis & 59 & 143 & 8.16 & 313 & Clamp & 43 & 155 & 6.42 & 347 \\
\hline & 76 & 137 & 10.1 & 560 & & & & & & & & & & \\
\hline & 69 & 137 & 9.14 & 255 & 12. Control & 56 & 145 & 7.68 & 72.9 & 21. Control & 44 & 147 & 6.17 & 406 \\
\hline & & & & & Clamp & 50 & 143 & 6.79 & 293 & Diuresis & 47 & 148 & 6.79 & 1190 \\
\hline \multirow{4}{*}{$\begin{array}{l}\text { 4. Control } \\
\text { Diuresis } \\
\text { Clamp }\end{array}$} & 47 & 159 & 7.09 & 24.2 & Diuresis & 53 & 143 & 7.31 & 1101 & Clamp & 44 & 147 & 6.32 & \\
\hline & 61 & 155 & 9.21 & 1398 & & & & & & & & & & \\
\hline & 43 & 151 & 6.24 & 118 & 13. Control & 72 & 143 & 9.80 & 17.5 & 22. Control & 74 & 148 & 10.4 & 795 \\
\hline & to & 201 & & & ClampR & 62 & 147 & 8.69 & 71.4 & Diuresis & 76 & 150 & 11.1 & 1817 \\
\hline \multirow{4}{*}{$\begin{array}{l}\text { 5. Control } \\
\text { Diuresis } \\
\text { Clamp }\end{array}$} & 33 & 149 & 4.58 & 1.5 & & & & & & Clamp & 63 & 154 & 9.4 & \\
\hline & 54 & 151 & 7.93 & 227 & 14. Control & 72 & 147 & 10.0 & 58.1 & Clamp & 60 & 157 & 9.11 & 1070 \\
\hline & 27 & 152 & 3.94 & 43.8 & ClampR & 63 & 147 & 8.84 & 101 & & & & & \\
\hline & & & & & Diuresis & 73 & 148 & 10.5 & 424 & & & & & \\
\hline \multirow{3}{*}{$\begin{array}{l}\text { 6. Control } \\
\text { Diuresis } \\
\text { Clamp }\end{array}$} & 41 & 149 & 5.77 & 10.1 & & & & & & & & & & \\
\hline & 49 & 155 & 7.30 & 881 & 15. ControlA & 45 & 144 & 6.20 & 8.9 & & & & & \\
\hline & 33 & 152 & 4.87 & 34.8 & Clamp & 28 & 149 & 4.07 & 101 & & & & & \\
\hline \multirow{3}{*}{$\begin{array}{l}\text { 7. Control } \\
\text { Diuresis } \\
\text { Clamp }\end{array}$} & 47 & 164 & 7.24 & 23.6 & 16. ControlA & 47 & 152 & 6.86 & 112 & & & & & \\
\hline & 54 & 164 & 8.51 & 600 & Clamp & 43 & 150 & 6.29 & 155 & & & & & \\
\hline & 47 & 163 & 7.32 & 156 & Diuresis & 46 & 150 & 6.61 & 341 & & & & & \\
\hline \multirow{3}{*}{$\begin{array}{l}\text { 8. Control } \\
\text { Diuresis } \\
\text { Clamp }\end{array}$} & 32 & 147 & 4.43 & 57.0 & 17. Control & 67 & 149 & 9.47 & 79.5 & & & & & \\
\hline & 37 & 151 & 5.43 & 1187 & ClampR & 60 & 149 & 8.58 & 161 & & & & & \\
\hline & 27 & 150 & 3.90 & 212 & Diuresis & 75 & 150 & 11.0 & 1085 & & & & & \\
\hline
\end{tabular}

* Abbreviations as in Table I. Superscript $\mathbf{A}=$ aldosterone administered, and superscript $\mathbf{R}=$ modified Ringer's solution infused. 
TABLE V

Representative control experiment*

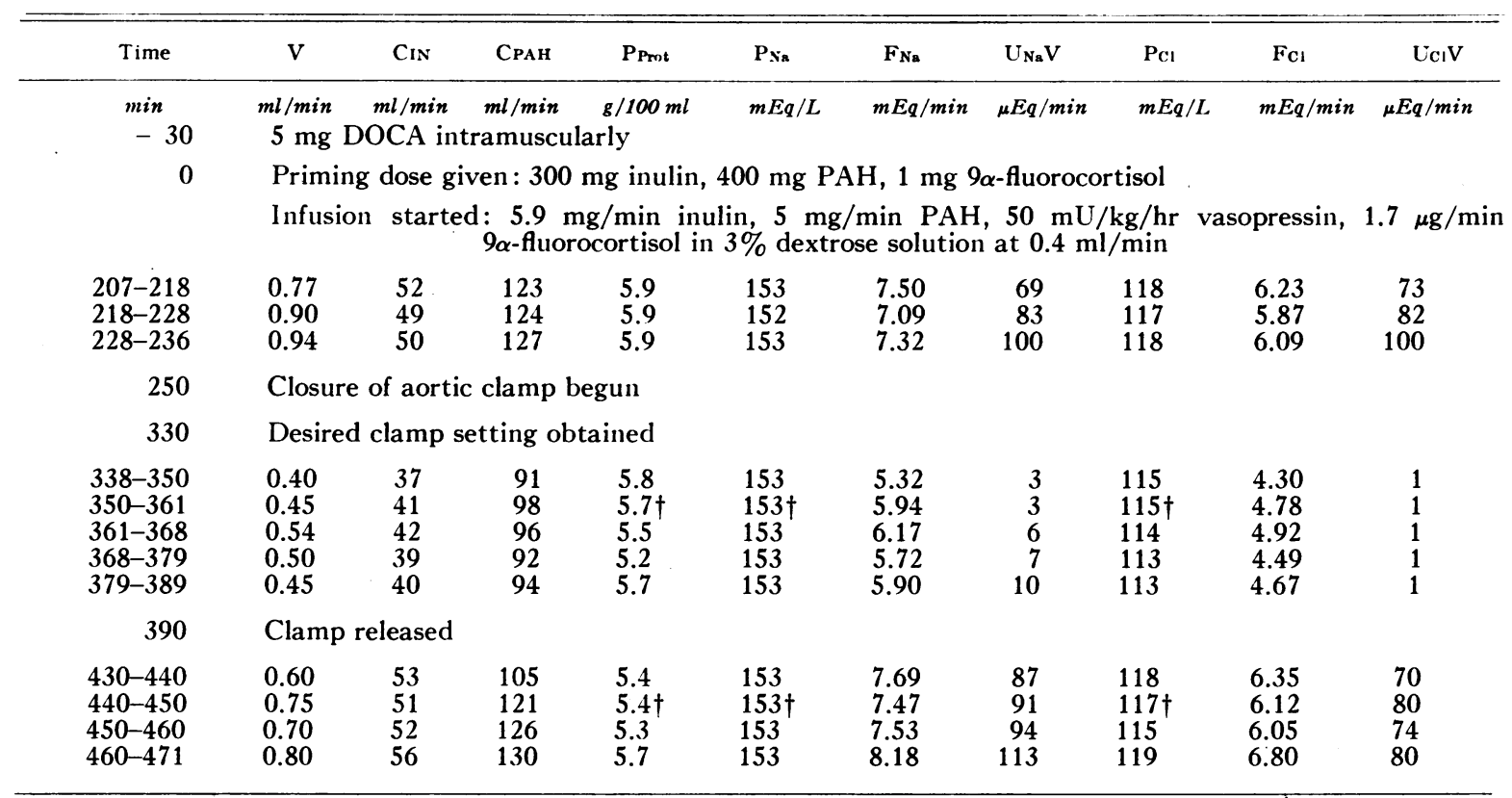

* Abbreviations as in Table I.

† Interpolated value.

showed that the increased excretion had occurred in spite of a spontaneous fall in filtered sodium. At the time of the experiment, the development of this "spontaneous experiment" could not be appreciated. Therefore, the clamp was manipulated in order to reduce sodium excretion to a value about $100 \mu \mathrm{Eq}$ per minute greater than the initial control values. As would be expected, filtered sodium was reduced still further below initial control values during these "clamp" periods. Changes in chloride filtration and excretion in this experiment were parallel with those described for sodium.

In four of the five experiments of this type (Table IV C), when sodium excretion in the "clamp" periods was set somewhat higher than the initial control rates, filtered sodium was found to be reduced well below control values. Experiment 19 , in which the "immediate clamping" technique was employed, was unusual in that control sodium excretion was only $11 \mu \mathrm{Eq}$ per minute in spite of the prior infusion of nearly $2,000 \mathrm{ml}$ of saline. The results, however, were qualitatively in agreement with the other experiments.

In all four experiments in which spontaneous "diuresis" periods were obtained, the increase in sodium excretion after the second load of saline was greater than the increase in filtèred sodium. Each dog had received more than $2,000 \mathrm{ml}$ of saline when the "diuresis" periods were collected; the volume of saline infused by the end of the experiments was 2,700 to $5,400 \mathrm{ml}$.

In all three types of experiments described above, when sodium excretion after saline loading was set 20 to $280 \mu \mathrm{Eq}$ per minute above control, filtered sodium was regularly lower than the control value. These results are illustrated in Figure 1. Each point represents a comparison of a group of "clamp" periods with its respective control. The 24 points represent all the experiments in the "diuresis first," "immediate clamping," and "double loading" categories. (Since there were 2 sets of "clamp" periods in experiments 1 and 22 , there are 2 more points than experiments.) In 20 of 24 comparisons, mean filtered sodium was less in "clamp" than in control periods, by approximately 300 to $4,700 \mu \mathrm{Eq}$ per minute. In four cases (points to the right of the vertical line), filtered sodium in the "clamp" periods was slightly above control, by an amount approximately equal to the increase in sodium excretion.

Chloride analyses were done in 13 of these 22 
experiments. The data are shown graphically in Figure 2, which is plotted like Figure 1. The results of these experiments are qualitatively comparable when expressed in terms of either chloride or sodium.

To rule out the possibility that aldosterone itself affects sodium excretion differently from large doses of DOCA and fluorocortisol, three dogs (experiments 1,15 , and 16 ) received aldosterone, in addition to the mineralocorticoids used in the other experiments. The data from one experiment are given in detail in Table $I$; the three experiments are summarized in Table IV and presented graphically in Figures 1 and 2. These experiments are entirely consistent with the other experiments in the same categories.

Plasma sodium concentration was relatively stable in most experiments. In 17 experiments, plasma sodium concentration varied less than 5 $\mathrm{mEq}$ per $\mathrm{L}$; in three, it increased 7, 6, and $9 \mathrm{mEq}$ per $\mathrm{L}$, respectively; in two others, plasma sodium decreased $8 \mathrm{mEq}$ per L. No significant differences related to changes in plasma sodium were noted.

In those experiments in which $0.82 \%$ saline was infused, plasma chloride concentration usially increased. In five experiments, modified Ringer's solution was infused instead of saline. In these experiments, the mean change in plasma chloride concentration was $+3 \mathrm{mEq}$ per $\mathrm{L}$ compared to a mean change of $+11 \mathrm{mEq}$ per $\mathrm{L}$ when saline was infused. There was no significant difference between the results of these two types of experiments.

Control experiments. In seven control experiments, the aorta was clamped, but saline was not infused. A representative experiment is shown in Table V. The experiments are summarized in Table VI A. In the control periods, sodium excretion was low, but rising slowly. When the clamp was set, decreasing filtered sodium $20 \%$, sodium excretion fell to $10 \%$ of the control rate. When the clamp was released, filtered and excreted sodium returned approximately to control values. Changes in filtered and excreted chloride were comparable. In each of the seven control experiments, shown in Table VI A, sodium excretion decreased when filtered sodium was reduced by use of the aortic clamp. In all experiments except one (no. 24), the decrease in sodium ex-

TABLE VI

Summary of experiments (types 4 and 5)

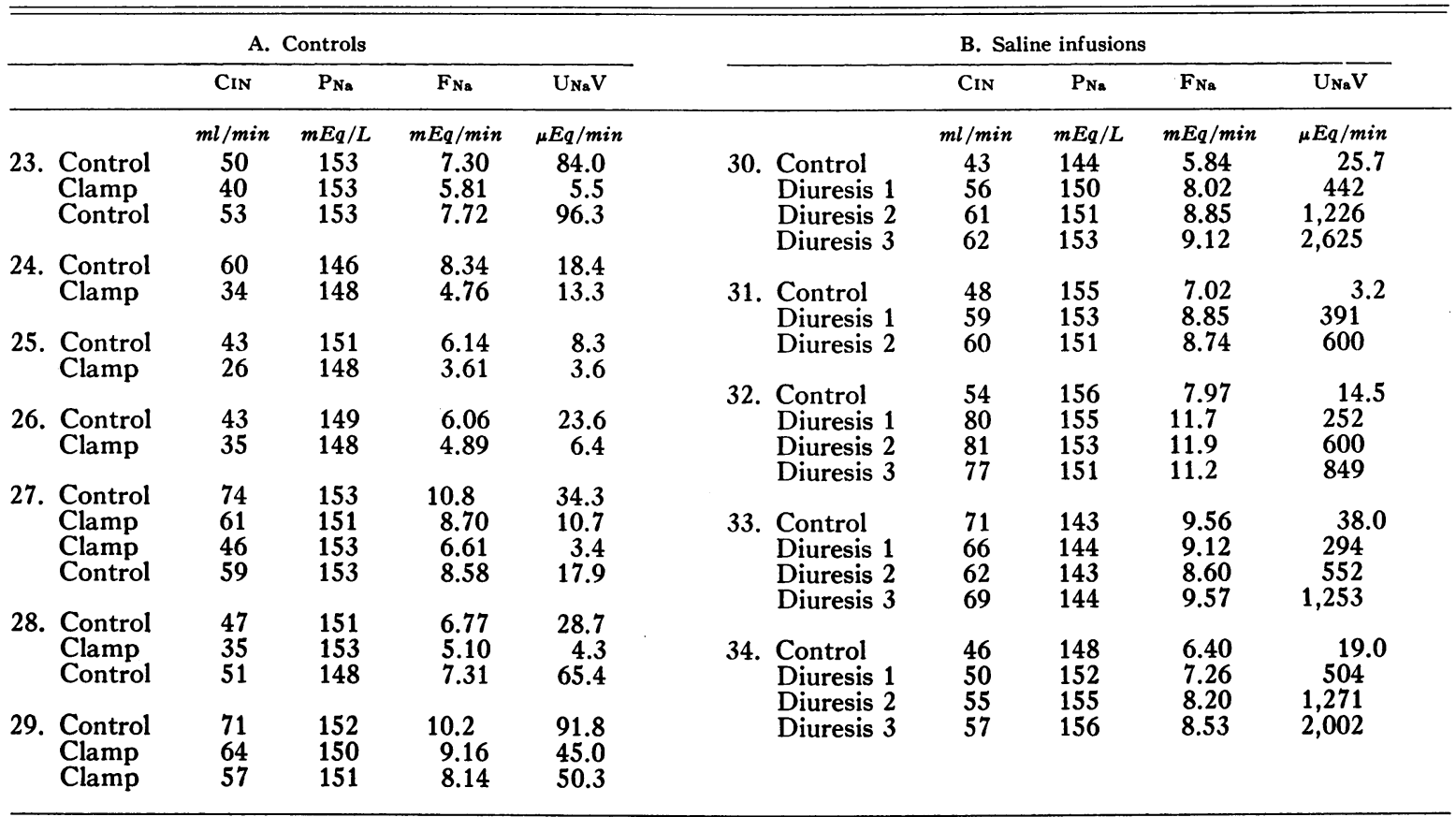

* Abbreviations as in Table I. 


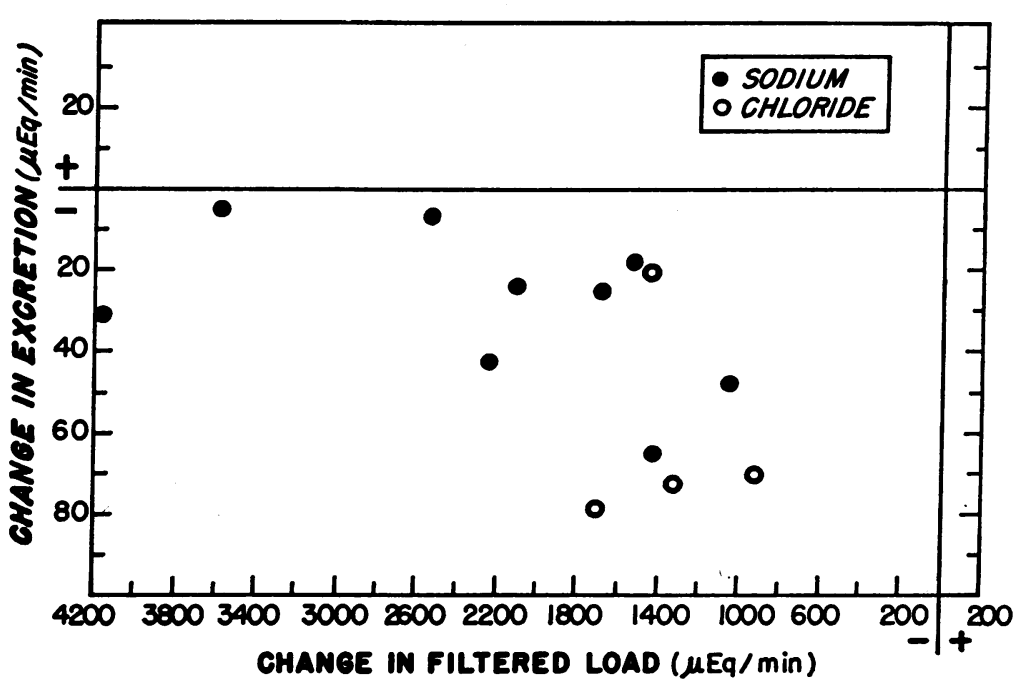

Fig. 3. Control experiments. Points represent mean changes, "clamp" minus control periods.

cretion was proportionately more than the decrease in filtered sodium. Since sodium excretion in the control periods was always low, the absolute decrease in sodium excretion during the "clamp" periods is necessarily small.

The data from the control experiments are shown graphically in Figure 3. This is plotted like Figures 1 and 2, with the mean change in excretion, "clamp" minus control, on the ordinate, and the corresponding change in filtered load on the abscissa. Comparison of Figure 3 with Figures 1 and 2 reveals that, with comparable decreases in filtered load, sodium or chloride excretion is regularly increased during saline loading (Figures 1 and 2), but decreased in the control experiments (Figure 3 ).

Saline infusions. In all the "double loading" experiments described above, the increase in sodium excretion between the control and "diuresis" periods was greater than the increase in filtered sodium. This suggested that with extreme degrees of saline loading it might regularly be possible to show a dissociation between changes in sodium excretion and changes in filtered sodium without the use of the aortic clamp. In five experiments, therefore, large volumes of saline were infused stepwise, and clearance periods were obtained without the use of a clamp. These experiments are summarized in Table VI B; one experiment is illustrated in Figure 4. Each point represents the mean value for a group of 3 to 5 clearance periods obtained at a relatively stable urine flow. Before saline infusion, sodium excretion was about $25 \mu \mathrm{Eq}$ per minute, and filtered sodium, about $5.8 \mathrm{mEq}$ per minute. After about $1 \mathrm{~L}$ of saline had been infused, sodium excretion had increased more than $400 \mu \mathrm{Eq}$ per minute to about $440 \mu \mathrm{Eq}$ per minute. Filtered sodium had increased almost $2,200 \mu \mathrm{Eq}$ per minute, much more than enough to account for the increase in excretion. An additional infusion of $1.3 \mathrm{~L}$ of

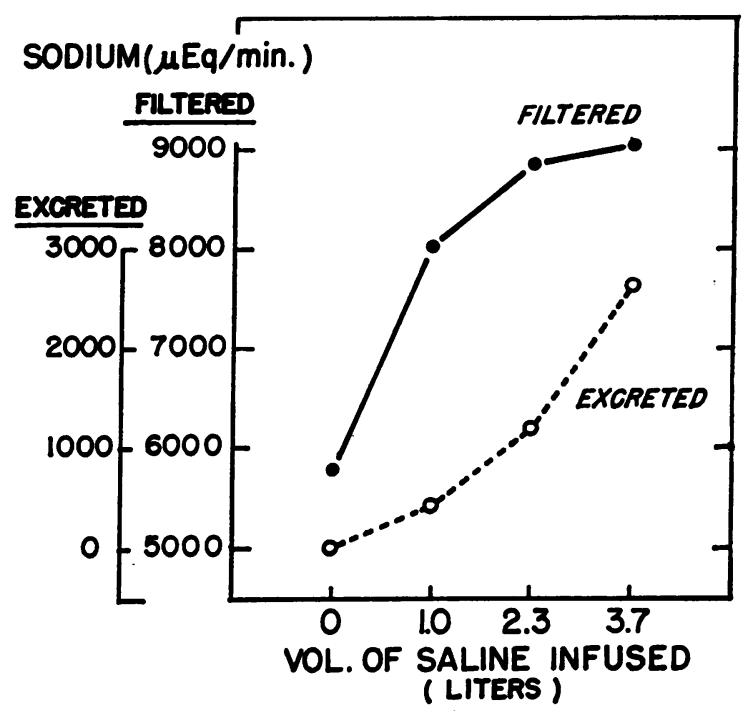

Fig. 4. "Saline infusion" eXperiment. Each point represents the mean for a group of 3 to 5 clearance periods. 
saline was given; the rate of sodium excretion increased almost $800 \mu \mathrm{Eq}$ per minute to more than $1,200 \mu \mathrm{Eq}$ per minute. This increase in excretion represented virtually the entire increment in filtered sodium, which was about $830 \mu \mathrm{Eq}$ per minute. More saline was infused until the total volume of infused material had reached $3.7 \mathrm{~L}$. Sodium excretion increased markedly from 1,200 to about $2,600 \mu \mathrm{Eq}$ per minute. This increase in excretion of some $1,400 \mu \mathrm{Eq}$ per minute was much greater than the concurrent increase in filtered sodium, which was less than $300 \mu \mathrm{Eq}$ per minute.

Results qualitatively similar to that shown in Figure 4 were obtained in each of the five experiments summarized in Table VI B. Initially, increases in sodium excretion usually represented only a fraction of concurrent increases in filtered sodium (as was also the case in the analogous "diuresis" periods of the "diuresis first" experiments). As the degree of saline loading was increased, this fraction tended to increase; finally, sodium excretion increased more than filtered sodium, or in some cases, increased even when filtered sodium decreased. The total volume of saline infused was from 2,700 to $4,400 \mathrm{ml}$. Casual observation and occasional auscultation of the lungs revealed no evidence of pulmonary edema or congestion.

Renal plasma flow. PAH clearance was measured in ten experiments summarized in Tables IV and VI; representative data are given in Tables I and V. Changes in renal plasma flow were usually about proportionate to changes in GFR. During aortic clamping, the filtration fraction was constant, or tended to increase slightly.

Albumin infusions. Plasma protein concentration fell in all the experiments described above (except the control experiments). The decrease in concentration between the control and the "clamp" periods varied from 0.5 to $3 \mathrm{~g}$ per $100 \mathrm{ml}$. To investigate the relation between dilution of plasma proteins and changes in sodium excretion, a series of experiments was performed in which changes in plasma protein concentration were minimized by an infusion of $0.82 \%$ saline containing $7 \mathrm{~g}$ of bovine albumin per $100 \mathrm{ml}$. The volume of the infusion was from 500 to $2,000 \mathrm{ml}$. The data, summarized in Table VII A, are qualitatively similar to those obtained in the comparable "diuresis first" experiments in which saline was infused (Table IV A). In experiments 35 through 42 , sodium excretion increased markedly after the infusion of albumin in saline; GFR also increased. When sodium excretion was reduced by clamping to rates 60 to $230 \mu \mathrm{Eq}$ per minute above control, filtered sodium was in every case below control. In experiments 43 and 44, sodium excretion increased only slightly after the albumin infusion; filtered sodium had decreased spontaneously in each experiment.

Adrenalectomized dogs. Five experiments, summarized in Table VII B, were done in adrenalectomized dogs to determine whether adrenal ("salt-losing") hormones play any part in causing the changes in sodium excretion described above. In four of the five experiments, filtered sodium was below control when sodium excretion was set about 100 to $250 \mu \mathrm{Eq}$ per minute above control by aortic clamping.

Angiotensin. Angiotensin was infused throughout the course of the four experiments summarized in Table VII C. In experiments 50 and 51, the angiotensin was infused intravenously; in experiments 52 and 53 , it was infused into the aorta just above the renal arteries. In the "clamp" periods of each experiment, sodium excretion was above control, while filtered sodium was less than the control value.

\section{DISCUSSION}

These experiments demonstrate that some factor other than increased filtered sodium or decreased aldosterone accounts for part of the sodium diuresis that follows saline infusion in the dog. De Wardener and associates (4) have previously reached a similar conclusion, based on decreases in GFR after saline infusions in some of their experiments. Since changes in plasma sodium were not given, however, and changes in GFR were usually small, it is uncertain whether filtered sodium decreased. Bojesen (12) has reported that after rapid intravenous administration of saline to dogs, the sodium diuresis precedes a demonstrable increase in GFR by 10 to $15 \mathrm{~min}$ utes. He suggested, however, that there is a "slight (unmeasurable) increase in the filtration rate, whereas the reabsorption of salt and water remains absolutely uninfluenced by changes in the water and salt loads." In human subjects (not treated with exogenous mineralocorticoids), Craw- 
MECHANISM OF SODIUM DIURESIS IN THE DOG

TABLE VII

Summary of experiments (types 6, 7, and 8)

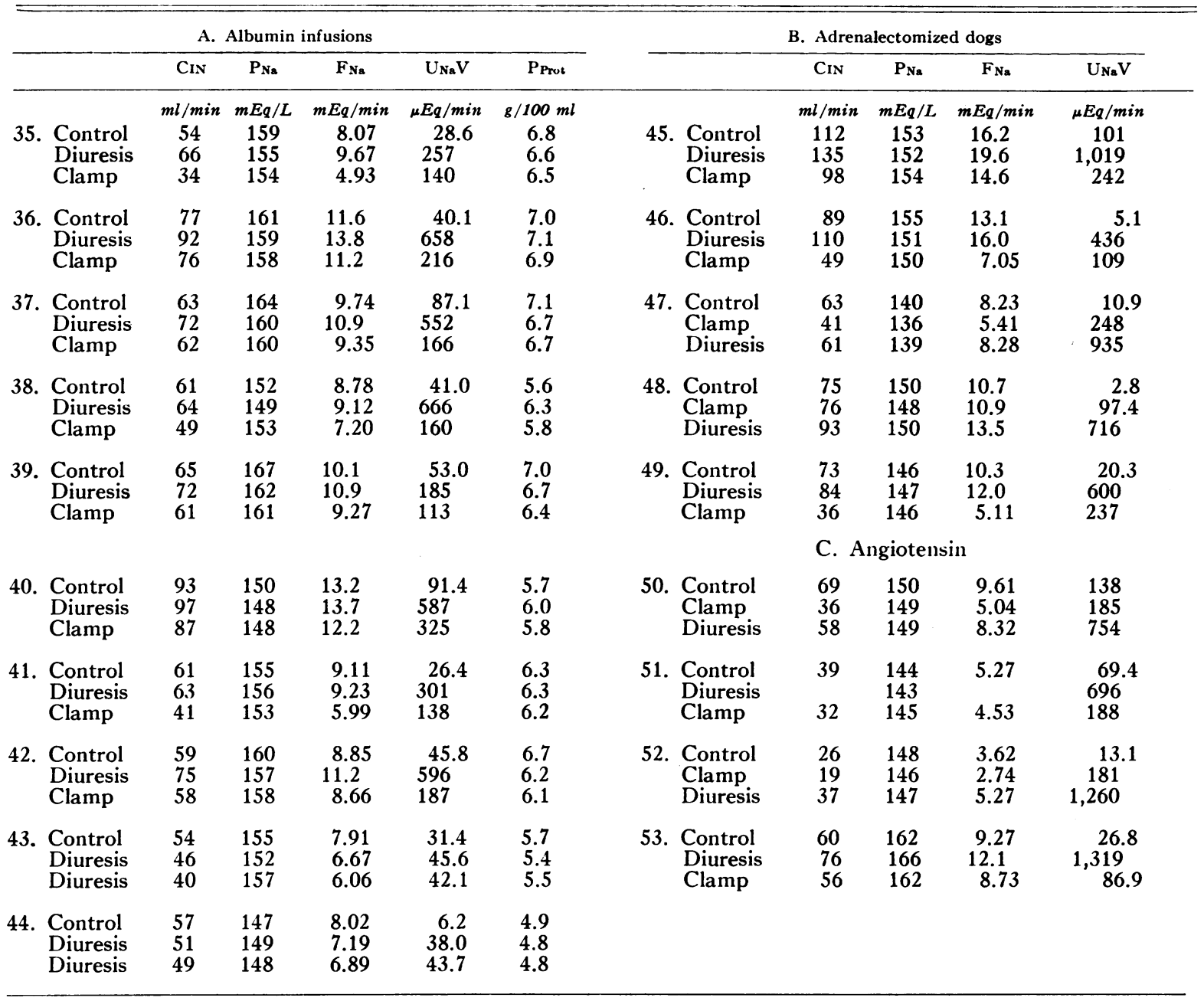

* Abbreviations as in Table I.

ford and Ludemann (13) found that sodium excretion increased moderately after infusion of 1 to $3 \mathrm{~L}$ of isotonic saline, while mean GFR decreased slightly. They concluded that there must be a mechanism capable of promoting sodium excretion by reducing tubular reabsorption at a constant filtered load. In contrast to these studies are the experiments of Wesson and co-workers (1), who infused a saline solution into dogs not pretreated with mineralocorticoids. They found that reabsorptive capacity for sodium, measured at a constant filtered load, increased rapidly. No explanation can be offered for the discrepancy between these results and the present data.
The decreases in filtered sodium produced by the technique of aortic clamping are reproducible and too large to be attributed to errors of measurement. It is very unlikely that the procedure of aortic clamping itself caused the increased sodium excretion during the "clamp" periods. Sodium excretion uniformly fell in the control experiments, in which comparable reductions in GFR were produced by the same technique, but saline was not infused. Other workers $(14,15)$ using similar techniques also have found that acute reductions in GFR uniformly result in decreased sodium excretion. Moreover, increased excretion with stable or decreased filtered sodium was demonstrated 
without the use of the aortic clamp, when large volumes of saline were infused ("saline infusion" experiments and "diuresis" periods of "double loading" experiments).

Plasma sodium concentration was relatively constant in most experiments. Any possible specific effect of acute elevations of plasma sodium not related to filtered load (16) is, therefore, presumably not relevant. Some error may be introduced into the calculation of sodium concentration in glomerular filtrate water by the assumption employed that the Donnan factor is linearly related to plasma protein concentration. Any error, however, would be at most 2 to $3 \%$ and cannot explain the results. The results of the experiments in which Ringer's solution was infused to keep the plasma chloride and bicarbonate concentrations relatively constant were not different from those in which saline was given. Changes in the concentration or proportions of the principal filtrable anions thus do not account for the results. Changes in excreted and filtered chloride were qualitatively comparable to those in sodium, and the conclusions derived from these experiments would not be altered if expressed in terms of chloride rather than sodium.

No measurements relevant to distribution of function among nephrons have been made. In most of the present experiments, reduction in GFR during clamping of the aorta was less than $40 \%$. Studies of maximal reabsorptive capacity for glucose (17) and potassium excretion (18) during reduction of GFR by similar techniques suggest that decreases in GFR of this magnitude are due to general reduction of GFR involving all nephrons, not to the dropping out of whole nephron units. In any case, evidence for a tubular factor decreasing sodium reabsorption was obtained in some experiments without the use of the aortic clamp (Figure 6). In addition, equivalent reductions of GFR by clamping in the control experiments resulted in decreased sodium excretion. It is therefore very unlikely that the increase in sodium excretion after saline loading is the result of intrarenal adjustments to dropping out of nephrons during clamping. The possibility exists, however, that more subtle changes in distribution of function among nephrons may occur during saline infusion and account for that part of the increase in sodium excretion not due to increased filtered sodium.

De Wardener and co-workers (4) have suggested that the increase in sodium excretion after saline infusion is essentially independent of changes in GFR. In their experiments, GFR increased or decreased with approximately equal frequency when saline was infused; excretion always increased. In all experiments in the present series in which comparable volumes of saline were given ("diuresis first," Table IV A), GFR increased. When the GFR was then reduced by clamping, the greater part of the increase in sodium excretion produced by the saline was eliminated. It would, therefore, seem reasonable to assume that part of the increase in sodium excretion is due to the increase in GFR associated with saline infusions in the dog.

The magnitude of the tubular effect accounting for the balance of the increase in excretion cannot be determined precisely from the present data. This effect could presumably be quantitated by measuring the increase in sodium excretion when filtered sodium after saline loading is reduced exactly to the control value. It was necessary, however, to reduce filtered sodium well below control in order to establish the presence of the tubular factor. The increase in excretion of approximately 80 to $100 \mu \mathrm{Eq}$ per minute found under these circumstances (Figure 1), therefore, represents the minimal change in tubular reabsorption after saline infusion.

The results of the "double loading" experiments suggest that the magnitude of this change in tubular reabsorption is related to the volume of saline infused. Before collection of the control periods, these dogs had received in excess of 1,500 $\mathrm{ml}$ of saline, an amount sufficient to activate the "tubular effect" in the "diuresis first" and "immediate clamping" experiments. At least 100 $\mu \mathrm{Eq}$ per minute of the elevated control rate of sodium excretion, therefore, presumably was due to the action of the tubular factor. After the second saline load, an additional "tubular effect" was demonstrated; at least 150 to $200 \mu \mathrm{Eq}$ per minute of the increase above control excretion was not related to increased filtered sodium (Figure 1). The initial infusion of more than $1,500 \mathrm{ml}$ thus had not elicited the maximal "tubular effect"; 


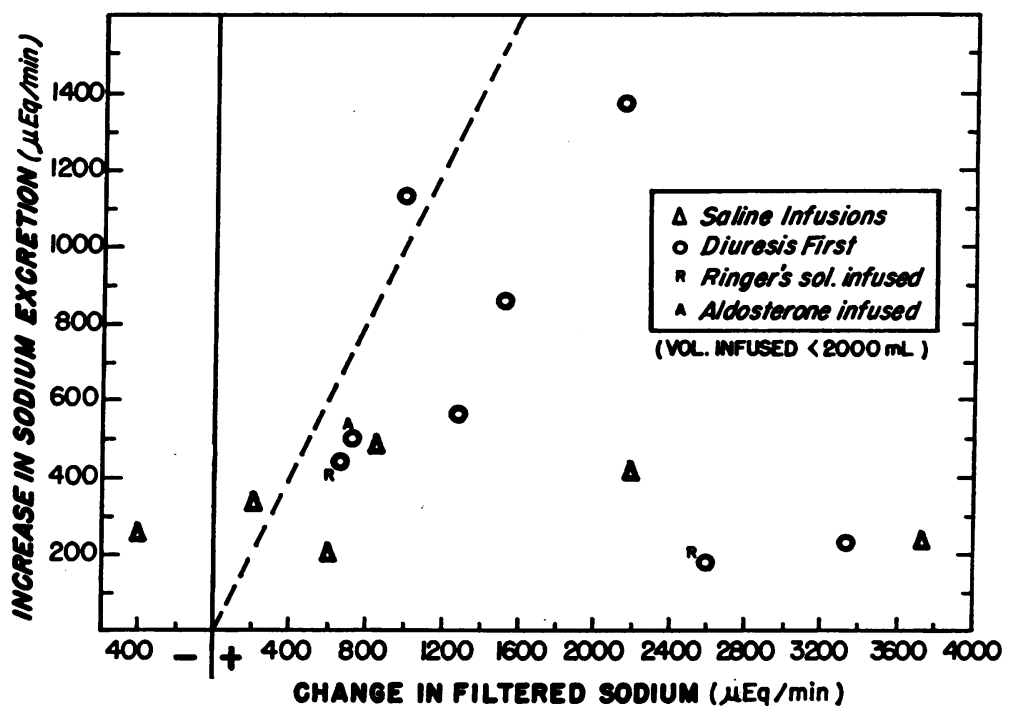

Fig. 5. Spontaneous periods: Less than 2,000 ML of SAline infuSEd. Points represent mean changes, "diuresis" minus control periods $(O)$ or "diuresis" minus periods immediately preceding $(\Delta)$.

the magnitude of this effect increased with increased saline loading.

The data summarized in Figures 5 and 6 also suggest that the magnitude of the "tubular effect" increases with progressive saline loading. All "spontaneous" (no clamping) postsaline periods are compared with their respective controls, or in the case of the "saline infusion" experiments, with the groups of periods immediately preceding. The mean change in filtered sodium, postsaline



Fig. 6. Spontaneous Periods: MORE than 2,000 ML OF SAline infuSed. Points represent mean changes, "diuresis" minus control periods ( $\boldsymbol{\square})$ or "diuresis" minus periods immediately preceding $(\triangle)$. 
minus control, is plotted on the abscissa and the change in excretion, on the ordinate. The data shown in Figure 5 are from those experiments in which the total volume of infusion at the time of collection of postsaline periods was less than $2,000 \mathrm{ml}$. The diagonal broken line represents equal changes in filtered and excreted sodium. Almost all the points are seen to lie to the right of this line, indicating that the increase in filtered sodium was mathematically more than sufficient to account for the increase in sodium excretion. In Figure 6 are shown the data from experiments in which more than $2 \mathrm{~L}$ of saline had been infused before collection of the postsaline periods. All but three points are seen to lie to the left of the broken line representing equal changes in filtered and excreted sodium. Thus, sodium excretion regularly increased more than filtered sodium when large amounts of saline were infused. ${ }^{4}$

It is suggested that the greater part of the increase in sodium excretion when relatively small volumes of saline are infused is related to an increase in filtered sodium. Most of the increase in GFR due to saline loading occurs during infusion of the first $2 \mathrm{~L}$ (Table VI B). As the volume infused becomes greater, further changes in GFR are variable and a decrease in tubular reabsorption apparently accounts for most of the additional increase in sodium excretion. These conclusions apply directly only to acute saline loading. The relative significance of glomerular and tubular factors in altered sodium excretion during chronic saline loading remains to be determined.

Three possible explanations for the decrease in tubular reabsorption of sodium have bee' tested. It has been proposed that a decrease in plasma protein concentration may decrease passive sodium reabsorption due to oncotic forces in the proximal tubule $(19,20)$. When dilution of

\footnotetext{
4 This phenomenon is also noted in a comparison of "diuresis" and control periods in experiments 11 and 16 (Table IV B) of the "immediate clamping" type, which is not included in Figures 5 and 6 because a group of "clamp" periods intervenes between the relevant spontaneous periods. Each dog received approximately 2,500 $\mathrm{ml}$ of saline. The increase in sodium excretion between the control and "diuresis" periods of experiment 11 in which only $1,800 \mathrm{ml}$ of saline was infused is probably too large to explain in this way; no explanation can be offered.
}

plasma proteins was prevented by adding albumin to the saline infusion (Table VII A), the decrease in tubular reabsorption of sodium was entirely comparable to that noted when saline alone was infused. Changes in protein oncotic forces, therefore, do not account for the "tubular effect" on sodium excretion.

De Wardener and associates $(4,21)$ have proposed that a humoral agent other than aldosterone is the "tubular factor" involved. Cross-perfusion experiments designed to provide evidence to this effect, however, failed to demonstrate the presence of a "salt-losing" hormone (4). Since decreased tubular reabsorption of sodium after saline loading was demonstrated in adrenalectomized dogs (Table VII B), secretion of adrenal "saltlosing" hormones cannot play a role in this phenomenon. Large amounts of vasopressin were infused in all our experiments; changes in endogenous antidiuretic hormone, therefore, are presumably eliminated as a possible factor.

Tobian, Coffee, Ferreira, and Meuli (22) have recently proposed that an agent altering tubular reabsorption of sodium may be formed by the kidney itself. Several lines of evidence (23-25) suggest that angiotensin may be such an agent. Angiotensin was infused throughout several experiments to eliminate changes in endogenous angiotensin activity as a factor. In an attempt to duplicate the high intrarenal concentrations that may be present during endogenous secretion, in two experiments the angiotensin was infused into the aorta above the renal arteries. Continuous infusions of angiotensin did not prevent decrease in tubular reabsorption of sodium after saline infusion. It therefore seems unlikely that changes in endogenous angiotensin secretion are the cause of this phenomenon.

\section{SUMMARY}

1) The mechanism of the sodium diuresis after saline infusion was studied in dogs in which filtered sodium could be reduced by means of a clamp around the aorta. Mineralocorticoids were administered in amounts sufficient to eliminate changes in endogenous secretion of aldosterone as a factor in these experiments. 2) In 22 acute experiments, control periods were obtained, after which dogs were infused with 1,400 to $5,400 \mathrm{ml}$ of 
isotonic saline or modified Ringer's solution. Plasma sodium was stable. When filtered sodium after saline loading was reduced significantly ( 300 to $4,700 \mu \mathrm{Eq}$ per minute) below control values by aortic clamping, sodium excretion was 20 to $280 \mu \mathrm{Eq}$ per minute above control. 3) When filtered sodium was comparably reduced in 7 control studies without saline infusion, excretion always fell, showing that no artifact was introduced by clamping. 4) In additional experiments, large volumes of saline were infused stepwise, without clamping. When the volume infused was less than $2,000 \mathrm{ml}$, the increase in filtered sodium was usually greater than the increase in sodium excretion. When the volume infused was more than $2,000 \mathrm{ml}$, sodium excretion usually increased more than filtered sodium. 5) It is concluded that neither increased filtered sodium nor decreased aldosterone secretion can account for the increase in sodium excretion that occurs after saline loading in the dog. Part of the increase must result from the action of another as yet undefined factor which decreases tubular reabsorption of sodium. The magnitude of this effect apparently increases with progressive saline loading. 6) Additional experiments suggest that the factor is not dilution of plasma proteins, adrenal "saltlosing" hormones, or angiotensin.

\section{REFERENCES}

1. Wesson, L. G., Jr., W. P. Anslow, Jr., L. G. Raisz, A. A. Bolomey, and M. Ladd. Effect of sustained expansion of extracellular fluid volume upon filtration rate, renal plasma flow and electrolyte and water excretion in the dog. Amer. J. Physiol. $1950,162,677$.

2. Ladd, M., and L. G. Raisz. Response of the normal dog to dietary sodium chloride. Amer. J. Physiol. 1949, 159, 149.

3. Wesson, L. G., Jr. Glomerular and tubular factors in the renal excretion of sodium chloride. Medicine 1957, 36, 281.

4. De Wardener, H. E., I. H. Mills, W. F. Clapham, and C. J. Hayter. Studies on the efferent mechanism of the sodium diuresis which follows the administration of intravenous saline in the dog. Clin. Sci. 1961, 21, 249.

5. Davies, D. F., and N. W. Shock. The variability of measurement of inulin and diodrast tests of kidney function. J. clin. Invest. 1950, 29, 491.

6. Hastings, A. B., H. A. Salvesen, J. Sendroy, Jr., and D. D. Van Slyke. Studies of gas and electrolyte equilibria in the blood. IX. The distribution of electrolytes between transudates and serum. J. gen. Physiol. 1927, 8, 701.

7. Folk, B. P., K. L. Zierler, and J. L. Lilienthal, Jr. Distribution of potassium and sodium between serum and certain extracellular fluids in man. Amer. J. Physiol. 1948, 153, 381.

8. Walser, M., D. G. Davidson, and J. Orloff. The renal clearance of alkali-stable inulin. $J$. clin. Invest. $1955,34,1520$.

9. Bratton, A. C., and E. K. Marshall, Jr. A new coupling component for sulfanilamide determination. J. biol. Chem. 1939, 128, 537.

10. Cotlove, E., H. V. Trantham, and R. L. Bowman. An instrument and method for automatic, rapid, accurate, and sensitive titration of chloride in biologic samples. J. Lab. clin. Med. 1958, 51, 461.

11. Gornall, A. G., C. J. Bardawill, and M. M. David. Determination of serum proteins by means of the biuret reaction. J. biol. Chem. 1949, 177, 751.

12. Bojesen, E. The renal mechanism of "dilution diuresis" and salt excretion in dogs. Acta physiol. scand. 1954, 32, 129.

13. Crawford, B., and H. Ludemann. The renal response to intravenous injection of sodium chloride solutions in man. J. clin. Invest. 1951, 30, 1456.

14. Thompson, D. D., and R. F. Pitts. Effects of alterations of renal arterial pressure on sodium and water excretion. Amer. J. Physiol. 1952, 168, 490.

15. Pitts, R. F., and J. J. Duggan. Studies on diuretics. II. The relationship between glomerular filtration rate, proximal tubular absorption of sodium and diuretic efficacy of mercurials. J. clin. Invest. 1950, 29, 372.

16. Wesson, L. G., Jr., and W. P. Anslow, Jr. Relationship of changes in glomerular filtration, plasma chloride and bicarbonate concentrations and urinary osmotic load to renal excretion of chloride. Amer. J. Physiol. 1955, 180, 237.

17. Thompson, D. D., M. J. Barrett, and R. F. Pitts. Significance of glomerular perfusion in relation to variability of filtration rate. Amer. J. Physiol. 1951, 167, 546.

18. Davidson, D. G., N. G. Levinsky, and R. W. Berliner. Maintenance of potassium excretion despite reduction of glomerular filtration during sodium diuresis. J. clin. Invest. 1958, 37, 548.

19. Malvin, R. L., W. S. Wilde, A. J. Vander, and L. P. Sullivan. Localization and characterization of sodium transport along the renal tubule. Amer. J. Physiol. 1958, 195, 549.

20. Bresler, E. H. Reabsorptive response of renal tubules to elevated sodium and chloride concentrations in plasma. Amer. J. Physiol. 1960, 199, 517.

21. Mills, I. H., H. E. de Wardener, C. J. Hayter, and W. F. Clapham. Studies on the afferent mecha- 
nism of the sodium chloride diuresis which follows intravenous saline in the dog. Clin. Sci. 1961, 21, 259.

22. Tobian, L., K. Coffee, D. Ferreira, and J. Meuli. The effect of renal perfusion pressure on the active transport of sodium out of distal tubular urine as studied with the "stop-flow" technique (abstract). J. clin. Invest. 1962, 41, 1404.

23. Leyssac, P. P., U. V. Lassen, and J. H. Thaysen. Inhibition of sodium transport in isolated renal tissue by angiotensin. Biochim. biophys. Acta (Amst.) 1961, 48, 602.

24. Brown, J. J., and W. S. Peart. The effect of angiotensin on urine flow and electrolyte excretion in hypertensive patients. Clin. Sci. 1962, 22, 1.

25. Laragh, J. H. Hormones and the pathogenesis of congestive heart failure: vasopressin, aldosterone, and angiotensin II. Further evidence for renaladrenal interaction from studies in hypertension and in cirrhosis. Circulation 1962, 25, 1015. 